\title{
Effect of Pigeonpea to Irrigation and Mulch Regime
}

\author{
M.A. Solanki ${ }^{1 *}$, A.L. Chalodia ${ }^{2}$, P.V. Dabhi ${ }^{1}$ and M.H. Fadadu ${ }^{1}$ \\ ${ }^{1}$ Department of Soil and Water Engineering, College of Agricultural Engineering and \\ Technology, Navsari Agricultural University, Dediapada - 393040, Gujarat, India \\ ${ }^{2}$ Department of soil and water management research unit, Navsari Agricultural University, \\ Navsari, Gujarat, India \\ *Corresponding author
}

\section{A B S T R A C T}

\section{Keywords}

Drip irrigation,

Biometric

parameter, Soil

temperature,

Moisture

conservation and

weather effect

\section{Article Info}

Accepted:

04 June 2019

Available Online:

10 July 2019
The field experiment was conducted at college farm, CAET, NAU, Dediapada, during rabi season 2017-18. The experiment was laid out in randomized block design with four replications, keeping five treatments of $\mathrm{T}_{1}$ - Drip irrigation with 0.6 PEF, $\mathrm{T}_{2}$ - Drip irrigation with 0.6 PEF, Drip + Black Plastic Mulch $50 \mu$ with (56\% coverage), $\mathrm{T}_{3}$ - Drip irrigation with 0.6 PEF, Drip + sugarcane trash mulch @ $5 \mathrm{t} / \mathrm{ha}$ with (56\% coverage), $\mathrm{T}_{4}$ surface irrigation IW/CPE: 1, $60 \mathrm{~mm}$ depth + sugarcane trash mulch @ $5 \mathrm{t} / \mathrm{ha}(56 \%$ coverage) and $\mathrm{T}_{5}$ - surface irrigation IW/CPE: 1 (control) with $60 \mathrm{~mm}$ depth. Growing of rabi pigeonpea resulted significantly higher yield attribute and biological yields in the treatment 0.6 PEF through drip irrigation with sugarcane trash mulch @ $5 \mathrm{t} / \mathrm{ha}$. Among mulch treatments, 0.6 PEF through drip with sugarcane trash mulch @ $5 \mathrm{t} / \mathrm{ha}$ was found to be significantly superior over other treatments with higher plant height at harvest (182.66 $\mathrm{cm})$, leaf area index $(0.88)$, stem girth $(16.46 \mathrm{~mm})$, root length and spread (40.05 and $27.38 \mathrm{~cm}$ ), number of pod per plant (273.26), number of seed per plant (981.89), number of seed per pod (3.59), pod yield per plant $(147.71 \mathrm{~g})$, grain yield per plant (100.63) and 100 seed weight $(11.20 \mathrm{~g})$. The grain yield registered under treatment $\mathrm{T}_{3}$ and $\mathrm{T}_{4}$ were $80.66 \%$ and $50.87 \%$ higher than surface (control). Black plastic mulch was found more effective in reducing soil moisture loss followed by organic mulch compared to no mulch which was associated with high moisture depletion and higher soil temperature.

\section{Introduction}

Pigeonpea plays an important role in the agricultural economy of India by virtue of its ability to fix atmospheric nitrogen in symbiotic association with Rhizobium. Secondly, their deep penetrating root system enable them to utilize the limited available moisture more efficiently than other crops including cereals and also contribute substantially to the loosening of the soil. Pigeonpea is traditionally grown of India in rainy season crop. Winter pigeonpea has a shorter maturity period. It gets the benefit of clear sky, low relative humidity, mild temperature and low incidence of pests and 
diseases. Besides, the crop has to face less competition from weeds and responds better to applied inputs. The preliminary varietal trials conducted at many places in south Gujarat in recent past provide conclusive evidences that winter pigeonpea yields are higher or equal to kharif crop, indicating its bright future prospects. In the present day of water scarcity, the optimum method of irrigation plays a vital role in economizing irrigation water and enhancing crop yield. Any extraneous material with which soil is covered called as mulch. It prevents the water loss by evaporation, moderate soil temperature, conserve soil moisture and suppress weed growth. Mulches of various kinds have been used to modify hydrothermal regime and crop growth have been found to depend upon the nature of mulch and the climatic environment. Plastic mulches have been extensively used in developed country and their favorable as well as unfavorable effects on the crop growth have been reported depending upon crops and climatic environment. In India, straw mulching has been practiced for moisture conservation and soil temperature moderation (Anonymous 1982).

\section{Materials and Methods}

The field experiment was conducted during the rabi season in 2017-18 at College Farm, CAET, NAU, Dediapada. The experiment was laid out in randomized block design with four replications, keeping five treatments of $T_{1}$ Drip irrigation with 0.6 PEF, $\mathrm{T}_{2}$ - Drip irrigation with 0.6 PEF, Drip + Black plastic mulch $50 \mu$ with (56\% coverage), $\mathrm{T}_{3}$ - Drip irrigation with 0.6 PEF, Drip + sugarcane trash mulch @ 5 t/ha with (56\% coverage), $\mathrm{T}_{4}$ - surface irrigation IW/CPE: 1, $60 \mathrm{~mm}$ depth + sugarcane trash mulch @ 5 t/ha (56\% coverage) and $\mathrm{T}_{5}$ - surface irrigation IW/CPE: 1 (control) with $60 \mathrm{~mm}$ depth. The soil of experimental plot was clayey loam in texture and slightly alkaline in reaction $(\mathrm{pH}$ 7.82).
The soil possessed normal electrical conductivity $(0.32 \mathrm{dS} / \mathrm{m})$, low availability organic carbon (0.34), low available nitrogen (204.32 kg/ha), medium available phosphorus (31.48 $\mathrm{kg} / \mathrm{ha})$ and low available potassium (66.55 kg/ha). Recommended doses of fertilizer, i.e. 20:40:0 kg NPK ha- ${ }^{1}$ was applied through urea and single super phosphate at time of sowing. Pigeonpea crop was sown in $21^{\text {st }}$ of November at a spacing of $60 \mathrm{x}$ 20: $120 \mathrm{~cm}$ in paired row experimentation and harvested at the physiological maturity stage at the end of April. During the pigeon pea crop period the mean weekly maximum temperature ranged from 26 to $40.7{ }^{\circ} \mathrm{C}$ with an average of 34.05 ${ }^{\circ} \mathrm{C}$ and mean weekly minimum temperature ranged from 14.3 to $25.3{ }^{\circ} \mathrm{C}$ with an average of $18.86{ }^{\circ} \mathrm{C}$, relative humidity varied from 18.4 to $78.0 \%$ with an average of $48.36 \%$, weekly bright sunshine hours per day varied from 4.8 to 10.3 hours with an average of 8.30 hr. Likewise the mean weekly wind velocity ranged from 1.4 to $6.5 \mathrm{~km} / \mathrm{hr}$ with an average of $3.2 \mathrm{~km} / \mathrm{hr}$, pan evaporation ranged from 2.30 to $16.8 \mathrm{~mm} \mathrm{~d}^{-1}$ with an average of 7.37 $\mathrm{mm} \mathrm{d}^{-1}$ (show in Fig. 1).

Irrigations were scheduled based on the USWB Class A pan evaporation rates for each treatment under drip irrigation and surface (control) irrigation and calculated following formula.

Opretion time $(\mathrm{m})=\frac{\mathrm{F} \times \mathrm{CPE} \times \mathrm{S} \times 60}{\mathrm{R} \times \mathrm{N}}$

Where, $\mathrm{F}=$ Fraction of pan evaporation $\mathrm{CPE}=$ Cumulative pan evaporation

$\mathrm{S}=$ Size of plot $\left(\mathrm{m}^{2}\right)$

$\mathrm{R}=$ Rate of discharge of an emitters (lph)

$\mathrm{N}=$ Number of emitters per plot

The surface control plots were irrigated in each furrow of paired rows through a dike from discharging outlet water point and 
calibrated volume into control plots separately.

Time required to irrigate plot $(\mathrm{m})=\frac{\text { Plot size( }(\mathrm{m})^{2} \mathrm{x} \text { Deph of firigiation water }(\mathrm{mm})}{\text { Discharge rate of irirgation water }(\mathrm{mm})}$

Initially, two common irrigations of $40 \mathrm{~mm}$ depth were given to all treatments for better establishment of the crop Pigeonpea variety GT-102 was used as test variety, before sowing seeds were treated with dithane M-45 fungicide, imida 35FS insecticide and Rhizobium culture. The growth and yield observations were recorded in ten plants randomly selected in each treatment.

\section{Soil temperature}

Soil temperature was determined using soil thermometers placed underneath the different mulch material. Soil temperature readings were taken every day at two different times of the day at (8:00 to 9:00 AM) and (5:00 to 6:00 PM). Soil thermometers were installed in each treatment at two depths namely; $5 \mathrm{~cm}$ and 15 $\mathrm{cm}$.

\section{Soil moisture distribution}

Soil moisture content was estimated gravimetric method, soil sample collected before and after irrigation and after weighing the samples were oven dried at $105^{\circ} \mathrm{C}$ for $24-$ $36 \mathrm{hr}$ attaining a constant weight. The following formula was used to calculate the soil moisture content.

moisture content $(\%)=\frac{\text { Fresh wt. }(\mathrm{g})-\text { Dry wt. }(\mathrm{g})}{\text { Dry wt. }(\mathrm{g})} \times 100$

Soil samples were taken at a spacing of about $30-45 \mathrm{~cm}$ distance from lateral line and Surface control in furrow at a depth of 0-10, 10-20 and 20-30 for studying soil moisture distribution pattern in each drip irrigation and surface control regime. This observation was made during periods of branching, flowering, pod development and maturity stage.

\section{Results and Discussion}

\section{Soil temperature}

Soil temperature is one of the main yield determinant factors that regulate biomass accumulation and growth of plants and it plays an important role in the growth and development of the canopy. Mulch material may differently affect the temperature of soils due to local the environmental conditions. Average for daily maximum, minimum, and mean soil temperatures observed in the present experiment were significantly higher in plastic mulch and lower in the organic mulched soil than the bare land soil respectively for different treatments (show in graphically depicted in figure $2 \mathrm{a}, \mathrm{b}$ and 3). Soil temperatures of up to $1.73{ }^{\circ} \mathrm{C}$ and $1.53{ }^{\circ} \mathrm{C}$ were recorded higher in black plastic mulch at $5 \mathrm{~cm}$ and $15 \mathrm{~cm}$ respectively. Soil temperature variation between maximum and minimum was highest when black plastic mulch and organic mulch were lowest variations. In general, variations in soil temperature increased with water deficit being greater with plastic and lower with organic mulch compared to no mulch at all different irrigation regimes. High temperature variations are reported negative impact on the general plant physiology.

\section{Soil moisture content distribution}

The lower soil moisture content distribution was observed in all treatments for before irrigation than the after irrigation. Higher gravimetric moisture content was observed in plastic mulch $\left(\mathrm{T}_{2}\right)$ with comparative in days and soil depth viz., before irrigation with average moisture content of 22.01, 23.29 and $24.41 \%$ respectively and after irrigation soil moisture of 31.65, 29.84 and $28.50 \%$ respectively. Among the treatment $\left(\mathrm{T}_{3}\right)$ of drip 
+ organic mulch moisture content was observed before irrigation average of 21.45, 22.93 and $24.02 \%$ respectively and after irrigation moisture content average of 30.79 , 29.44 and $27.94 \%$ respectively. In treatment $\left(\mathrm{T}_{4}\right)$ surface + organic mulch was soil moisture content observed before irrigation with an average 21.42, 23.09 and $23.98 \%$ respectively and after irrigation moisture content with an average of 30.56, 29.40 and $28.13 \%$ respectively. Only drip treatment $\left(\mathrm{T}_{1}\right)$ was observed before irrigation of soil moisture content with an average of 19.82, 21.85 and $23.08 \%$ respectively and after irrigation with an average of $29.18,28.12$ and $27.17 \%$ respectively. In the treatment $\left(\mathrm{T}_{5}\right)$ surface (control) moisture content was observed before irrigation average of 20.33, 22.22 and $22.85 \%$ respectively and after irrigation an average of $29.23,28.19$ and $27.24 \%$ respectively (show in graphically depicted in figure $3,4,5,6,7$ and 8 ).

Fig.1 Meteorological data during the crop period

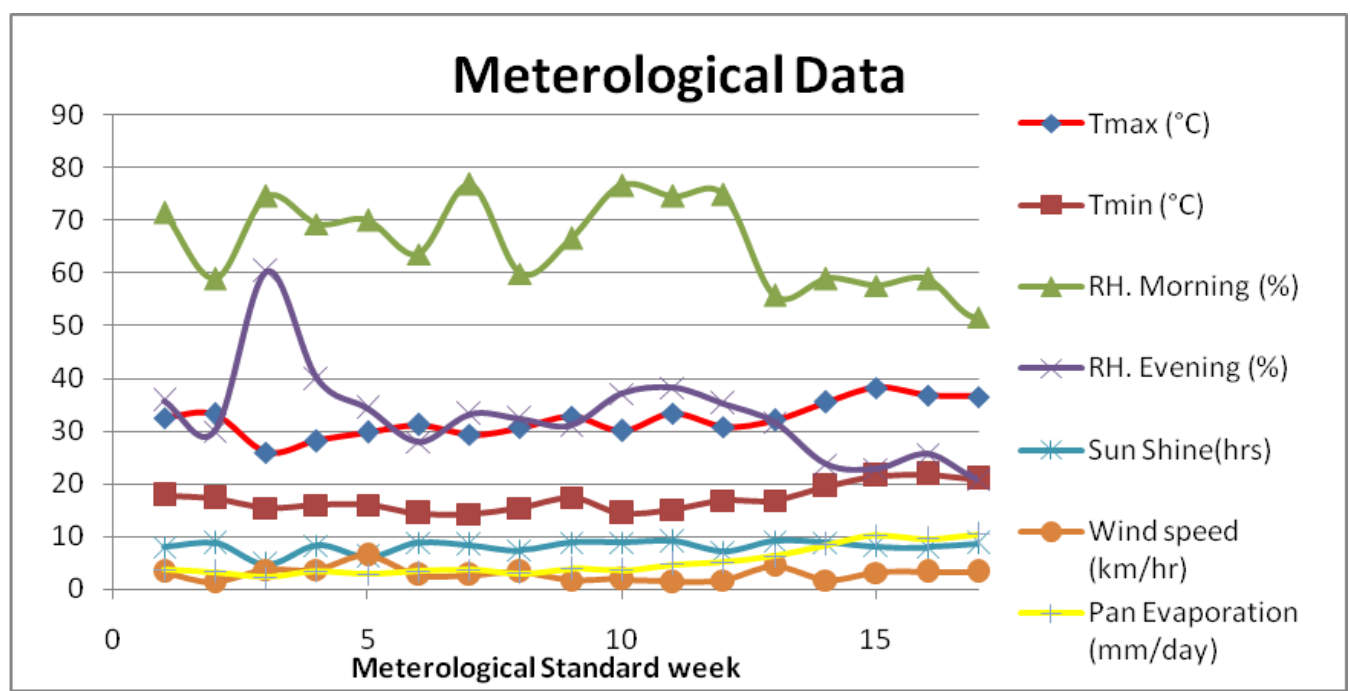

Fig.2a Soil temperature observed in the evening at 5 and $15 \mathrm{~cm}$ depth of all treatments

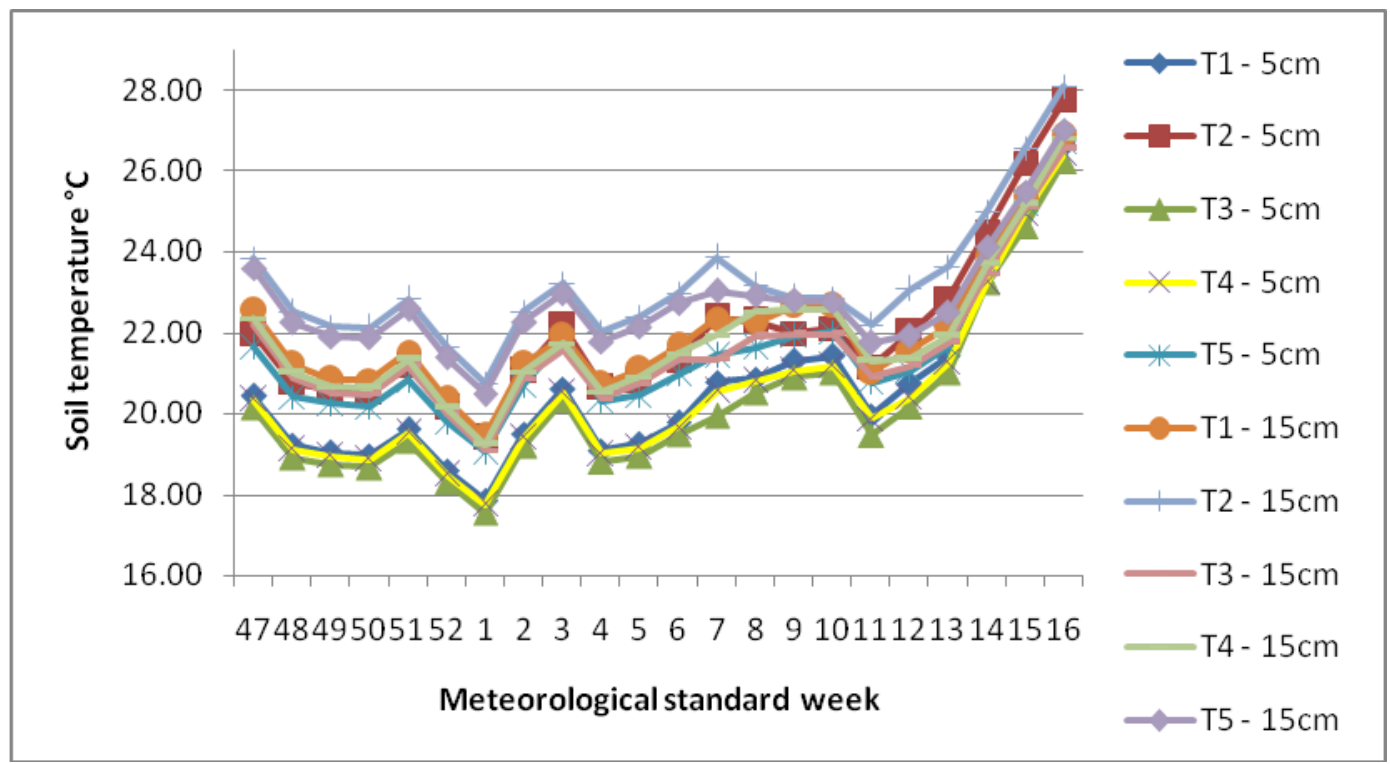


Fig.2b Soil temperature observed in the evening at 5 and $15 \mathrm{~cm}$ depth of all treatments

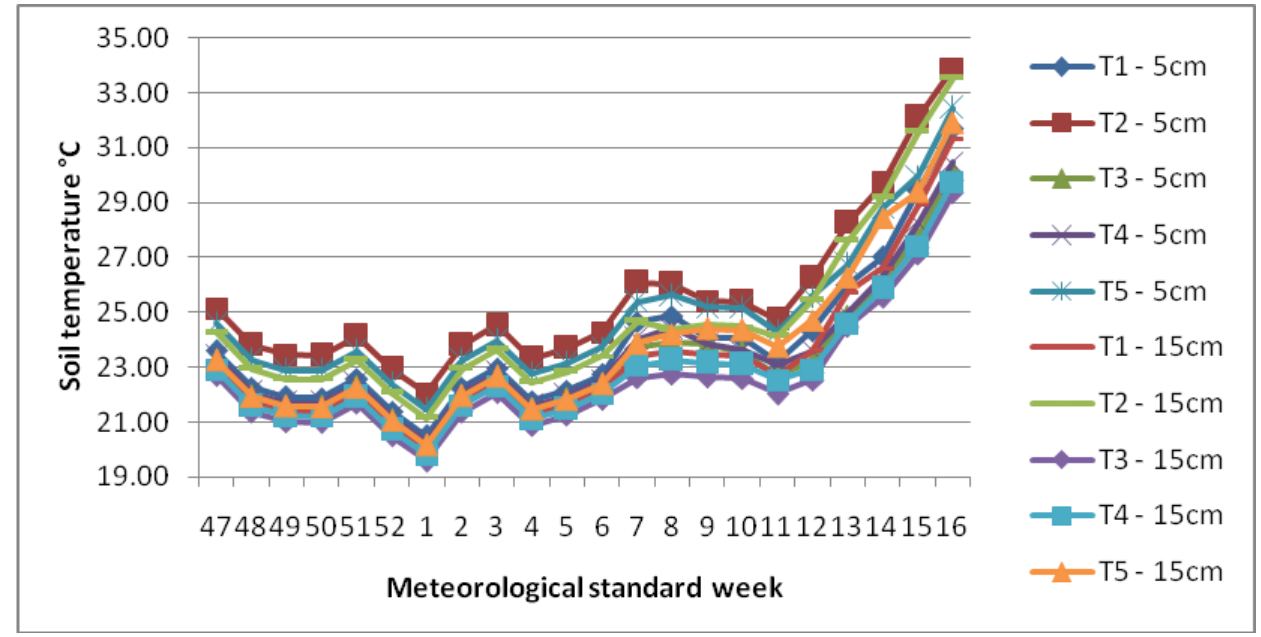

Fig.3 Soil moisture content observed before irrigation at 0-10 $\mathrm{cm}$ depth

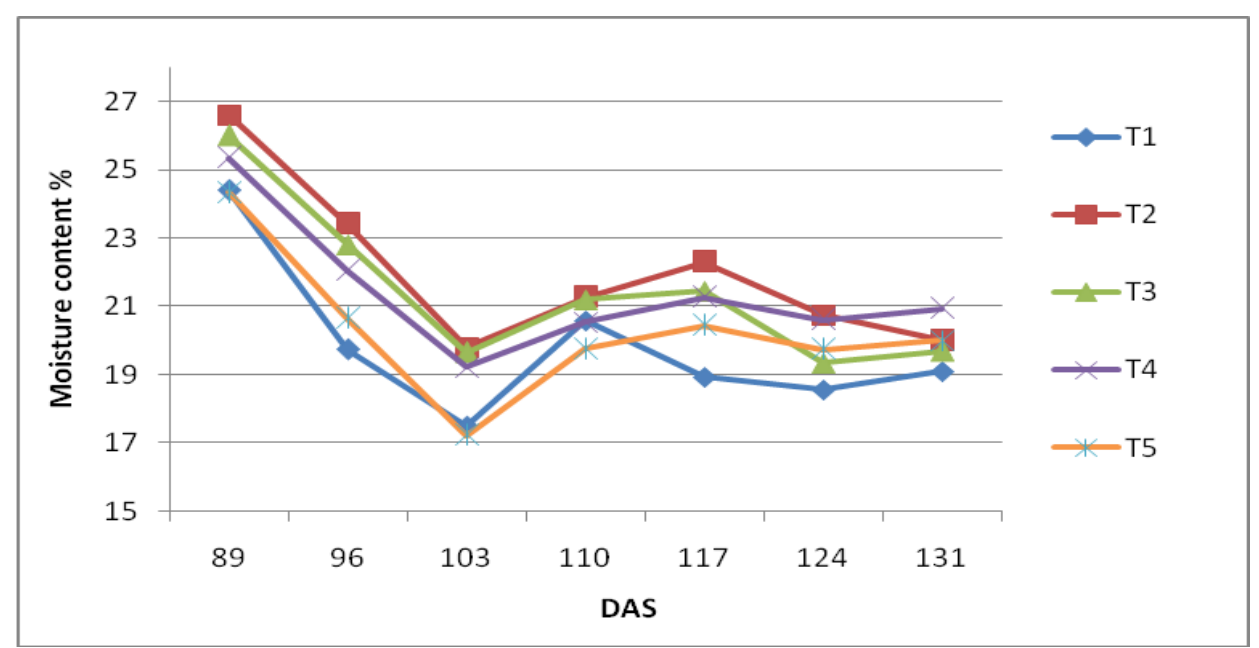

Fig.4 Soil moisture content observed before irrigation at 10-20 cm depth

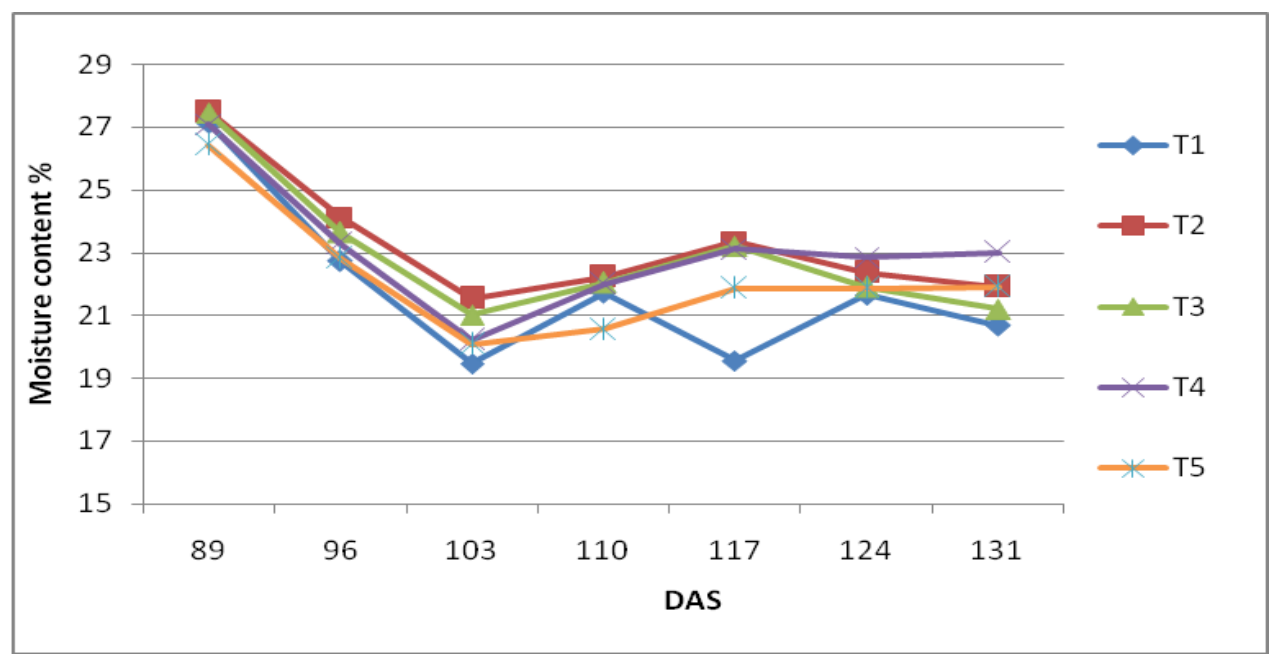


Fig.5 Soil moisture content observed before irrigation at 20-30 cm depth

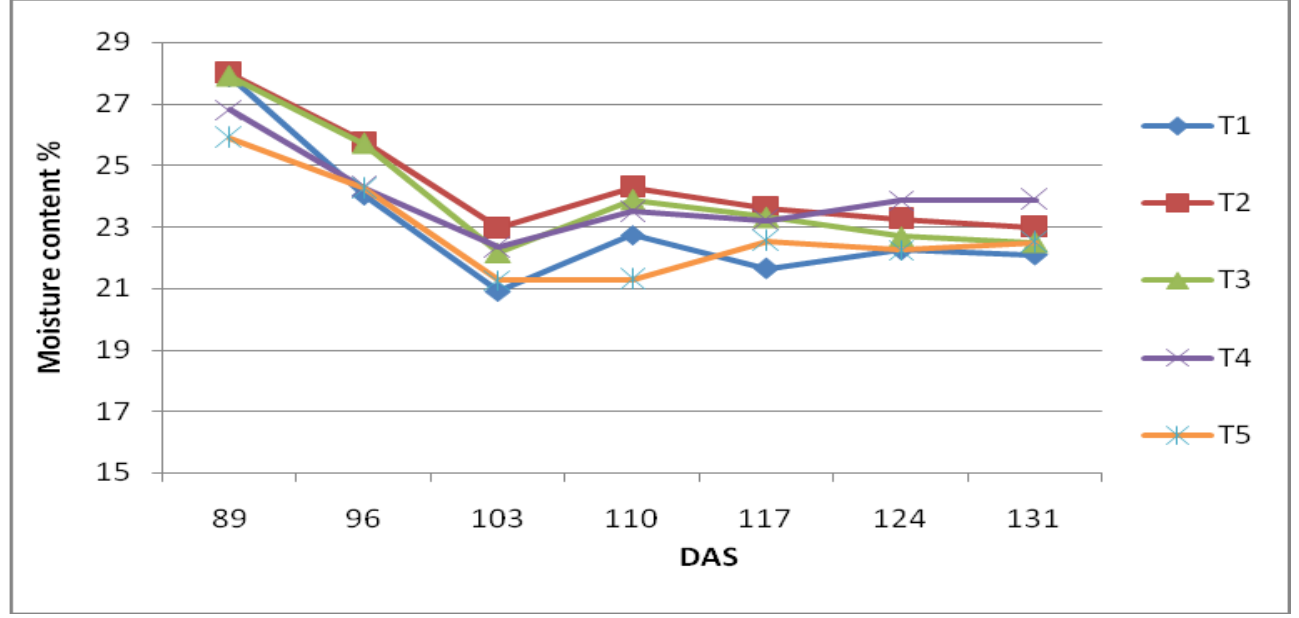

Fig.6 Soil moisture content observed after irrigation at $0-10 \mathrm{~cm}$ depth

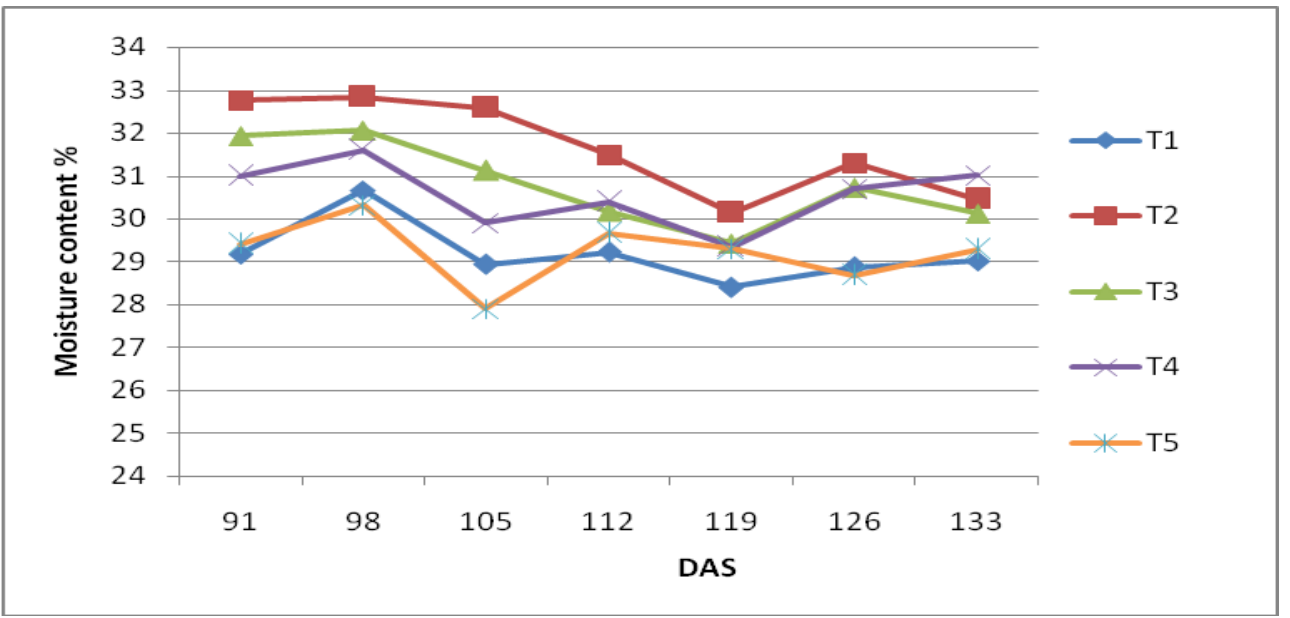

Fig.7 Soil moisture content observed after irrigation at 10-20 cm depth

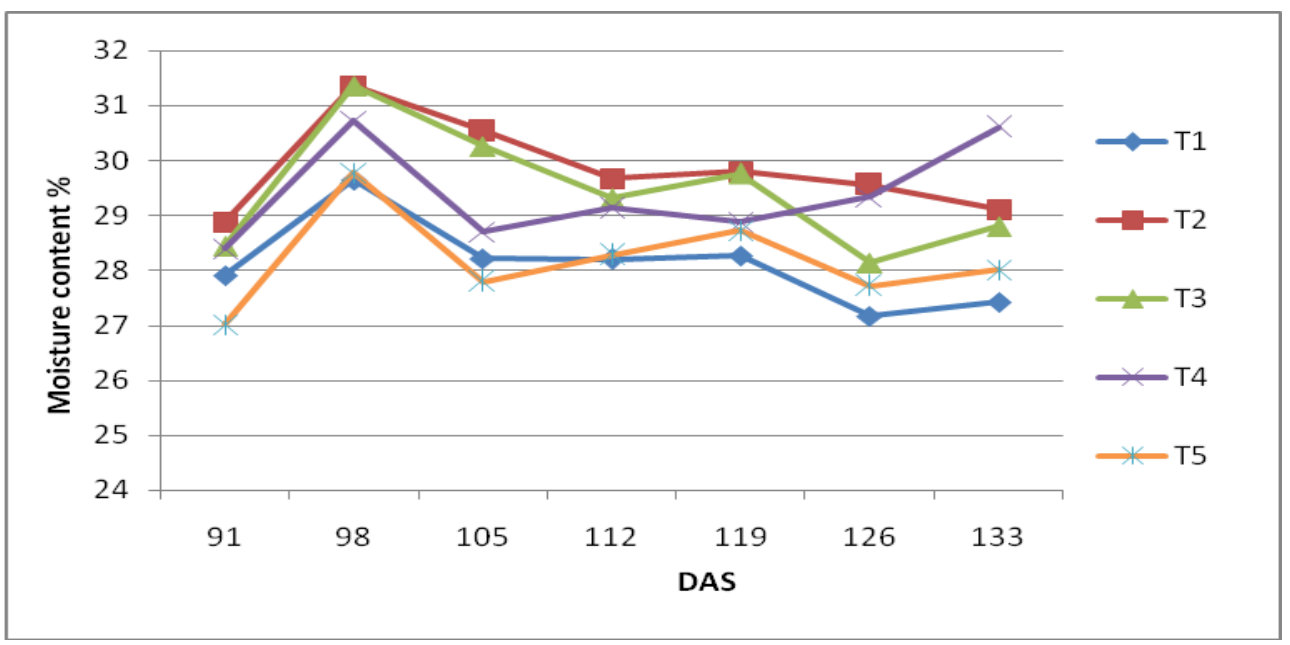


Fig.8 Soil moisture content observed after irrigation at 20-30 $\mathrm{cm}$ depth

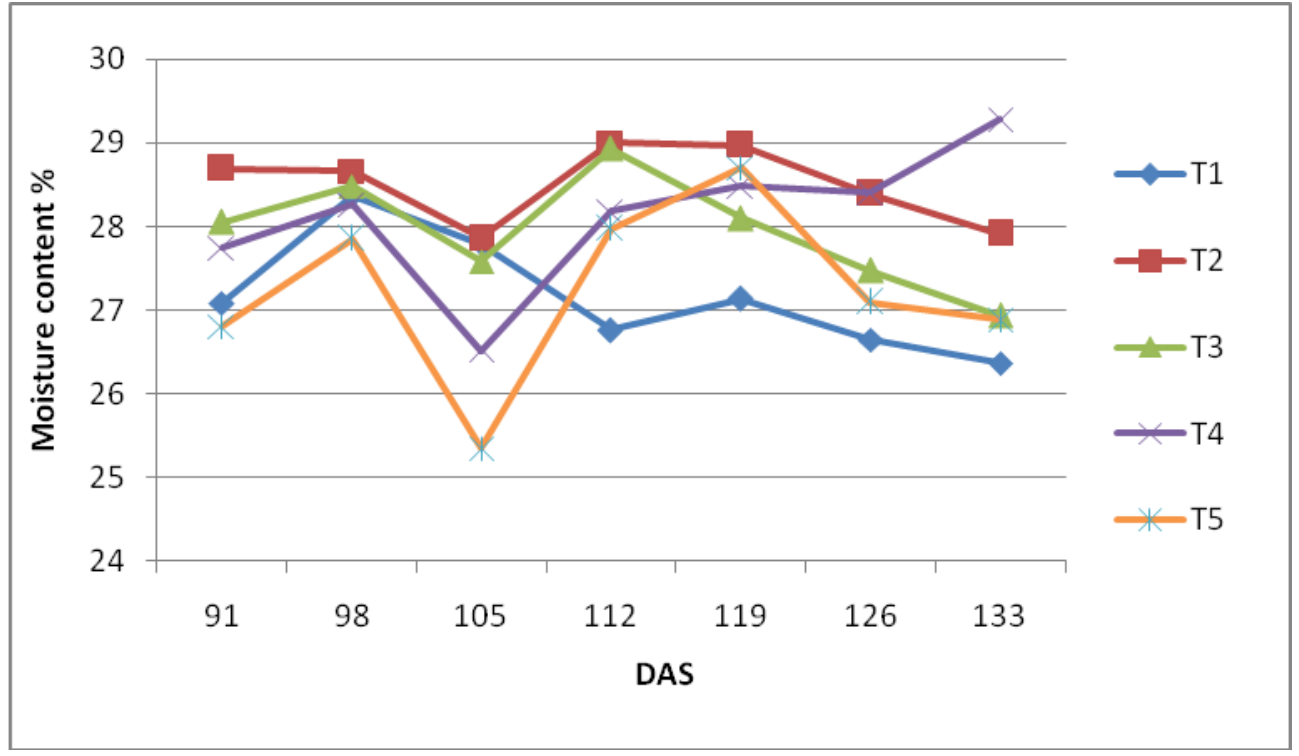

Table.1 Effect of irrigation and mulch on pigeonpea growth parameter

\begin{tabular}{|c|c|c|c|c|c|c|c|c|c|}
\hline \multirow[t]{2}{*}{ Treatments } & \multicolumn{2}{|c|}{ Plant population } & \multirow{2}{*}{$\begin{array}{c}\text { Plant } \\
\text { height } \\
\text { (cm) At } \\
\text { harvest }\end{array}$} & \multirow{2}{*}{\begin{tabular}{|c|} 
Leaf \\
area \\
index \\
At \\
harvest
\end{tabular}} & \multirow{2}{*}{$\begin{array}{l}\text { Stem } \\
\text { girth } \\
(\mathrm{mm})\end{array}$} & \multirow{2}{*}{$\begin{array}{l}\text { Root } \\
\text { length } \\
(\mathrm{cm})\end{array}$} & \multirow{2}{*}{$\begin{array}{c}\text { Root } \\
\text { spread } \\
\text { (cm) }\end{array}$} & \multirow{2}{*}{$\begin{array}{c}\text { Days } \\
\text { to } \\
\text { flowering }\end{array}$} & \multirow{2}{*}{\begin{tabular}{|c|} 
Days \\
to \\
pod \\
initiation
\end{tabular}} \\
\hline & $\begin{array}{c}\text { Initial } \\
\text { plant } \\
\text { stands } \\
(\%)\end{array}$ & $\begin{array}{l}\text { Final plant } \\
\text { stands at } \\
\text { harvest } \\
(\%)\end{array}$ & & & & & & & \\
\hline $\mathbf{T}_{1}$ & 87.50 & 96.25 & 175.13 & 0.68 & 15.06 & 33.31 & 22.81 & 87.00 & 101.00 \\
\hline $\mathbf{T}_{2}$ & 81.25 & 93.75 & 176.15 & 0.64 & 15.28 & 34.15 & 22.96 & 84.00 & 100.00 \\
\hline $\mathbf{T}_{3}$ & 83.75 & 88.75 & 182.66 & 0.88 & 16.46 & 40.05 & 27.38 & 87.00 & 101.00 \\
\hline $\mathbf{T}_{4}$ & 68.75 & 80.00 & 178.14 & 0.78 & 15.74 & 36.91 & 24.58 & 89.00 & 104.00 \\
\hline $\mathbf{T}_{5}$ & 70.00 & 92.50 & 169.15 & 0.58 & 13.57 & 30.47 & 20.64 & 89.00 & 104.00 \\
\hline mean & 78.30 & 90.25 & 176.24 & 0.71 & 15.22 & 34.98 & 23.67 & 87.20 & 102.00 \\
\hline S.Em. \pm & 3.87 & 3.22 & 2.55 & 0.03 & 0.39 & 1.66 & 1.22 & - & - \\
\hline $\begin{array}{l}\mathrm{CD}(\mathrm{P} \leq \\
0.05 \%)\end{array}$ & $11.91^{*}$ & $9.92 *$ & $7.85^{*}$ & $0.10 *$ & $1.21 *$ & $5.11 *$ & $3.76^{*}$ & - & - \\
\hline C.V. \% & 9.88 & 7.13 & 2.89 & 9.20 & 5.17 & 9.49 & 10.31 & - & - \\
\hline
\end{tabular}

* Significant at $\mathrm{P} \leq 0.05 \%$ 
Table.2 Effect of irrigation and mulch on grain yield attributes of pigeonpea

\begin{tabular}{|c|c|c|c|c|c|c|c|}
\hline Treatments & $\begin{array}{l}\text { Number } \\
\text { of pods } \\
\text { per plant }\end{array}$ & $\begin{array}{l}\text { Number } \\
\text { of seeds } \\
\text { per plant }\end{array}$ & $\begin{array}{l}\text { Number } \\
\text { of seeds } \\
\text { per pod }\end{array}$ & $\begin{array}{c}\text { Pod } \\
\text { weight } \\
\text { per } \\
\text { plant } \\
\text { (g) }\end{array}$ & $\begin{array}{l}\text { Grain } \\
\text { yield } \\
\text { per } \\
\text { plant } \\
\text { (g) }\end{array}$ & $\begin{array}{c}100 \\
\text { seed } \\
\text { weight } \\
\text { (g) }\end{array}$ & $\begin{array}{c}\text { Grain } \\
\text { yield } \\
\text { (kg/ha) }\end{array}$ \\
\hline $\mathbf{T}_{1}$ & 246.64 & 827.61 & 3.36 & 132.92 & 91.00 & 10.72 & 2718.92 \\
\hline $\mathbf{T}_{2}$ & 210.88 & 684.13 & 3.25 & 114.26 & 73.44 & 10.52 & 2353.25 \\
\hline $\mathbf{T}_{3}$ & 273.26 & 981.89 & 3.59 & 147.71 & 100.63 & 11.20 & 3318.49 \\
\hline $\mathbf{T}_{4}$ & 250.85 & 877.98 & 3.50 & 134.90 & 93.15 & 10.97 & 2771.36 \\
\hline $\mathbf{T}_{5}$ & 201.14 & 669.80 & 3.33 & 105.63 & 61.02 & 9.88 & 1836.87 \\
\hline mean & 236.55 & 808.30 & 3.41 & 127.08 & 83.85 & 10.66 & 2599.78 \\
\hline S.Em. \pm & 6.00 & 27.57 & 0.09 & 4.88 & 3.94 & 0.23 & 108.17 \\
\hline $\mathrm{CD}(\mathrm{P} \leq 0.05 \%)$ & $18.48^{*}$ & $84.95^{*}$ & NS & $15.03 *$ & $12.15^{*}$ & $0.69 *$ & $333.29 *$ \\
\hline C.V. \% & 5.07 & 6.82 & 5.31 & 7.68 & 9.41 & 4.22 & 8.32 \\
\hline
\end{tabular}

* Significant at $\mathrm{P} \leq 0.05 \%$, NS- non significant

\section{Effect on growth attributes}

The results pertaining to morphogenic characters viz., plant population, plant height, leaf area index, stem girth, root length and spread at time of harvest, days to flowering and days to pod initiation are presented in Table 1 as affected by different irrigation and mulching treatments. The initial plant stand after 13 DAS germination and final plant stand at harvest ranged from $68.75 \%$ to $87.50 \%$ and $80.00 \%$ to $96.25 \%$ respectively. During initial establishment stage of crop in organic mulch, more insects and pests were attacked resulting in low plant population in organic mulch as compared to other treatments. The results of days to flowering and pod initiation was early in treatment $\mathrm{T}_{2}$ (drip + black plastic mulch $50 \mu$ with $56 \%$ coverage) flowering (84 Days) and pod initiation (100 Days) than treatments $T_{3}$ and $\mathrm{T}_{1}$ respectively.

The plastic mulching resulted in early germination due to increase in soil temperature and higher moisture conservation than the organic mulch; subsequent vigorous growth of crop might be the reasons for early flowering and pod initiation in mulching with drip irrigation treatments resulting in early synchronized flowering and pod initiation. Early germination, vigorous crop growth, early flowering and podding of pigeonpea crop might be the reason for early maturity in mulching treatments. Similar results were observed by Mahalakshmi (2011) for rabi pigeonpea. The plant height was initially increased higher (establishment and vegetative stage) in treatment $T_{2}$ after that lead to reproductive and maturity stage in significantly higher plant observed in treatment $\mathrm{T}_{3}$ registered of $182.66 \mathrm{~cm}$ and at par with treatments $T_{4}, T_{2}$ and $T_{1}$. Significant leaf area index at harvest of 0.88 was recorded in treatment $T_{3}$ and it was at par with treatment $\mathrm{T}_{4}(0.78)$ and $\mathrm{T}_{4}$ at par with treatment $\mathrm{T}_{1}(0.68)$ and $\mathrm{T}_{1}$ at par with treatments $\mathrm{T}_{2}$ and $\mathrm{T}_{5}$. The average LAI increased at a lower rate up to $90 \mathrm{DAS}$ and thereafter it increased linearly with the ontogeny of the plant, reaching a peak value at 120 DAS, then due to age effect of leaves, it was found to decrease linearly and at harvest the LAI recorded lower value. These results were in conformity with those reported by Mahalakshmi et al., (2011). Leaf area 
expansion is dependent on leaf turgor potential (Boyer, 1970). Further, it is well documented that cell enlargement is very sensitive to water deficits and the consequence is a marked reduction in leaf area (Begg and Turner, 1976 and Hasio et al., 1976). Stem girth was recorded significantly higher in $\mathrm{T}_{3}$ treatment $(16.46 \mathrm{~mm})$ which was at par with treatments $\mathrm{T}_{4}$ and $\mathrm{T}_{2}$. Here also $\mathrm{T}_{3}$ treatment recorded significantly higher root length (40.05) and spread $(27.38 \mathrm{~cm})$ which was at par with treatment $T_{4}, T_{2}$ and $T_{1}$. Whereas favorable soil, water and plant water balance were shown to stimulate increased activity of meristematic cells and cell elongation of internodes resulting in a higher growth rate of stem in turn promoting the plant height of pigeonpea (Gardner et al., 1985 and Jaleel et al., 2009). Similar results were reported by Selva (2009).

\section{Effect on yield attributes and yield}

The results pertaining to number of pods per plant, number of seeds per plant, number of seed per pod, pod weight per plant, grain yield per plant, 100 seed weight and grain yield (Table 2) as affected by different irrigation and mulching treatments were obtained. In all the possible combinations of treatment $\mathrm{T}_{3}$ (0.6 PEF of irrigation with organic mulch (drip + sugarcane trash mulch @ $5 \mathrm{t} /$ ha with (56\% coverage)) showed its superiority than rest of the treatment combinations in respect to number of pods per plant recorded (273.26) and number of seed per plant (981.89) than the treatment $\mathrm{T}_{4}$ recorded of (250.85 \& 877.98) and which was statically at par with treatment $\mathrm{T}_{1}$ registered of (246.64 \& 827.61) respectively. Number of seeds per pod was not significantly influenced by various treatment data showed in table 2 , However, among the different treatment results, the mulch treatment $\mathrm{T}_{3}$ recorded numerically higher number of seeds per pod of 3.59 which was higher than treatments $T_{4}$
(3.50) and $T_{1}$ (3.36). Pods weight (147.71 $\mathrm{g} /$ plant) and grain yield per plant (100.63 g) were statically at par with treatments $\mathrm{T}_{4}$ and $\mathrm{T}_{1}$. Also treatment $\mathrm{T}_{3}$ test $(100 \mathrm{seed})$ weight recorded significantly higher grain weight $(11.20 \mathrm{~g})$ which was at par with treatments $\mathrm{T}_{4}$, $\mathrm{T}_{1}$, and $\mathrm{T}_{2}$ whereas significantly higher grain yield in treatment $\mathrm{T}_{3}(3318.49 \mathrm{~kg} / \mathrm{ha})$ was recorded which was higher than treatment $\mathrm{T}_{4}$ $(2771.36 \mathrm{~kg} / \mathrm{ha})$ and statistically at par with treatment $T_{1}$. Lowest grain yield were recorded in treatment $T_{2}(2353.25 \mathrm{~kg} / \mathrm{ha})$ and $\mathrm{T}_{5}(1086.87 \mathrm{~kg} / \mathrm{ha})$. The increase in pod and grain yield per plant under drip irrigation might be due to adequate water supply at all the critical growth stages and ultimately reflected in higher uptake of nutrients which might have resulted in better pod development and grain feeling. This finding is in conformity with those reported by Sarkar et al., (2010) and Mahalakshmi (2011).

This implies that drip irrigation favours in terms of yield attributes in comparison to remaining levels of irrigation, due to availability of sufficient moisture supply throughout the entire growth period. These results are in close conformity with the findings of Solanki (2006) and Mahalakshmi et al., (2011) for rabi pigeon pea. Among all the yield parameters, treatment $\mathrm{T}_{3}$ proved its superiority over rest of the treatments (with mulching and without mulching).

It was concluded that based on results, it is recommended that pigeonpea (cv. GT-102) can be grown during rabi season under Dediapada Taluka region irrigated with drip irrigation (discharge 4 lph) $0.6 \mathrm{PEF}+$ sugarcane trash mulch @ 5 t/ha, throughout the crop life which was given maximum yield of $3318.49 \mathrm{~kg} / \mathrm{ha}$. It was also observed that the second highest yield was found in surface irrigation (IW/CPE: 1, $60 \mathrm{~mm}$ depth + sugarcane trash mulch @ 5 t/ha) with 2771.36 $\mathrm{kg} / \mathrm{ha}$ over rest of the treatments. 


\section{References}

Anonymous (1982). The use of plastic in agriculture Ist report of national committee on use of plastic in agriculture. 57 - 59.

Begg, J. E. and Turner, N. C. (1976). Crop Water Deficits. Advances in Agronomy, 28: $161-217$.

Boyer, J. S. (1970). Leaf enlargement and metabolic rates in corn, soybean and sunflower at various leaf water potentials. Plant Physiology, 46: 233 235.

Gardener, F. P., Pearu, R. B. and Mitchell, R. L. (1985). Physiology of crop plants. Lowa State University press. Lowa, 327.

Hasio, T. C., Acevedo, E., Fereras, E. and Henderson, D. W. (1976). Water stress, growth and osmotic adjustment. Philosophical Transaction of Royal Society of London series, B- 273: 479 500.

Jaleel, C. A., Manivannan, P., Wahid, A., Farooq, M., Somasundaram, R and Panneerselvam, R. (2009). Drought stress in plants: a review on morphological characteristics and pigments composition. International Journal of Agriculture and Biology, 11: $100-105$.

Mahalakshmi, K. (2011). Response of rabi pigeonpea to different levels of drip irrigation. M.Sc. (Agri.) thesis submitted to college of agriculture Acharya N.G. ranga agricultural university Rajendranagar, Hyderabad.

Mahalakshmi, K., Kumar, K. A., Reddy, M. D. and Devi, M. U. (2011e4). Response of rabi pigeonpea [Cajanus cajan (L.)] to different levels of drip irrigation. Journal of Research, 39(4): 101 - 103.

Sarkar, A., Sarkar, S., Zaman, A. and Rana, S.K. (2010) Performance of summer sesamum under different irrigation regimes and nitrogen levels. Indian Journal of Agronomy, 55 (2): 143-146.

Selva, R. A. (2009). Drip fertigation studies in maize (Zea mays L.)-Bhendi (Abelmoschus esculentus L. Moench) cropping sequence. Ph.D. Thesis, TNAU, Coimbatore.

\section{How to cite this article:}

Solanki, M.A., A.L. Chalodia, P.V. Dabhi and Fadadu, M.H. 2019. Effect of Pigeonpea to Irrigation and Mulch Regime. Int.J.Curr.Microbiol.App.Sci. 8(07): 43-52.

doi: https://doi.org/10.20546/ijcmas.2019.807.006 